Volume 9, Issue 1 (Winter 2017)

\title{
A View beyond Delft: Johannes Vermeer's Woman with a Lute and Its Relationship to Frans van Mieris
}

Adriaan E. Waiboer

AWaiboer@ngi.ie

Recommended Citation:

Adriaan E. Waiboer, “A View beyond Delft: Johannes Vermeer's Woman with a Lute and Its Relationship to Frans van Mieris," JHNA 9:1 (Winter 2017) DOI: 10.5092/jhna.2017.9.1.16 Available at https://jhna.org/articles/view-beyond-delft-johannes-vermeers-woman-with-a-luterelationship-frans-van-mieris/

Published by Historians of Netherlandish Art: https://hnanews.org/ Republication Guidelines: https://jhna.org/republication-guidelines/

Notes: This PDF is provided for reference purposes only and may not contain all the functionality or features of the original, online publication. This PDF provides paragraph numbers as well as page numbers for citation purposes.

ISSN: 1949-9833 


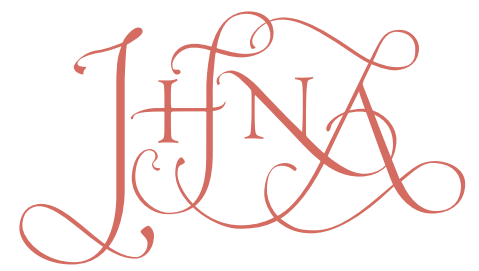

JOURNAL OF HISTORIANS OF NETHERLANDISH ART

A VIEW BEYOND DELFT: JOHANNES VERMEER'S WOMAN WITH A LUTE AND ITS RELATIONSHIP TO FRANS VAN MIERIS

\section{Adriaan E. Waiboer}

This article provides a critical overview of Johannes Vermeer's responses to Frans van Mieris's work before focusing on a case of direct influence involving the former's Woman with a Lute from the Metropolitan Museum of Art, New York, and the latter's Woman Playing a Theorbo-Lute from the National Gallery of Scotland, Edinburgh, which seems to have been overlooked in the literature on Vermeer. The Delft artist's admiration for the work of his Leiden contemporary is also visible in the former's Guitar Player (London, Kenwood House). In contrast to Vermeer's paintings, van Mieris's music scene made a strong impact on contemporary artists. D01:10.5092/jhna.2017.9.1.16

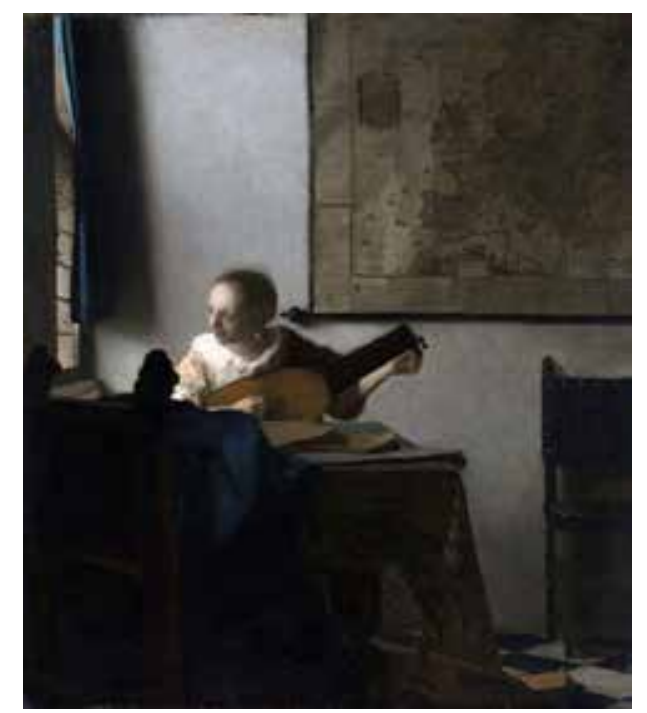

Fig. 1 Johannes Vermeer, Woman with a Lute, ca. 1662-64, oil on canvas, $51.4 \times 45.7 \mathrm{~cm}$. New York, The Metropolitan Museum of Art, Bequest of Collis P. Huntington, 1900, inv. 25.110 .24 (artwork in the public domain)

1 Although Dutch genre painters active in the third quarter of the seventeenth century were based in different cities in the Dutch Republic, their work bears strong similarities in style, subject matter, composition, and technique. They frequently appropriated ideas from each other's paintings and attempted to surpass each other's work in verisimilitude, technical prowess, and aesthetic appeal. A striking example of this vibrant artistic rivalry is Johannes Vermeer's (1632-1675) relationship with Frans van Mieris (1635-1681). Although contact between the two artists has 
not been documented, they unquestionably knew each other personally-their respective residences, Delft and Leiden, were located merely twenty kilometers apart. Vermeer was three years older than van Mieris, but there is little doubt that he looked up to the latter's social and financial status. ${ }^{1}$ The Delft artist, moreover, strongly admired his contemporary's work. Ever since Edouard Plietzsch suggested in 1939 that some of van Mieris's paintings served as an example to Vermeer, scholars have identified a number of connections between the Delft artist's works and those of his Leiden colleague. ${ }^{2}$ Inspired by a conversation I had with Walter shortly before his death, this article provides a critical overview of Vermeer's responses to van Mieris's work. It will then focus on a case of direct influence involving Woman with a Lute (fig. 1) from the Metropolitan Museum of Art, New York, which seems to have been overlooked in the literature on Vermeer.

Although Vermeer remained a resident of Delft throughout his life, his work is inextricably linked to that of contemporary painters living elsewhere. His early history and genre paintings suggest that he studied the work of, among others, Jacob van Loo (1614-1670) from Amsterdam, Gerrit van Honthorst (1592-1656) from Utrecht, Nicolaes Maes (1634-1693) from Dordrecht, Gerard ter Borch (1617-1681) from Deventer, and Gerrit Dou (1613-1675) from Leiden. Vermeer's admiration of Dou's work probably led him to the latter's star pupil, van Mieris. Around 1657 this precocious artist found a new niche in Dutch genre painting by combining his master's delicate brushwork with the genteel interactions of ter Borch's high-life scenes. ${ }^{3}$ The refined technique, description of textures, and illusionism in Dou's and van Mieris's work of the 1650s certainly strongly appealed to Vermeer. They reverberated in some of his early genre scenes of the late 1650s, including The Letter Reader (Dresden, Gemäldegalerie Alte Meister, Staatliche Kunstsammlungen), Cavalier and Young Woman (New York, Frick Collection) and The Milkmaid (Amsterdam, Rijksmuseum). ${ }^{4}$

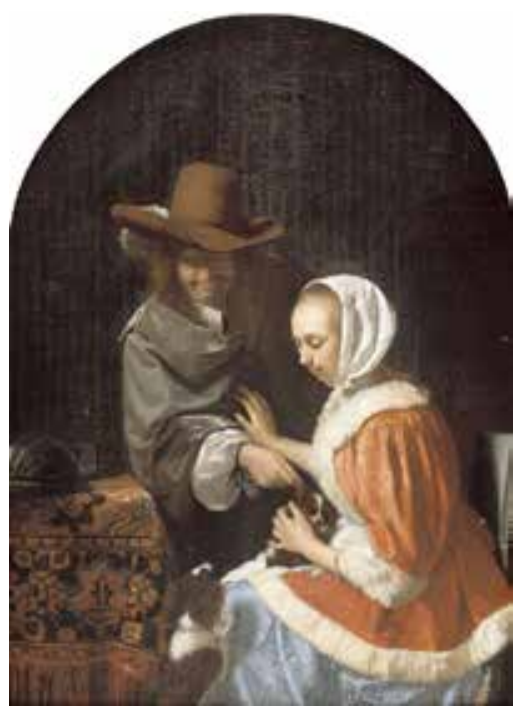

Fig. 2 Frans van Mieris, Man and a Woman with Two Dogs, known as "Teasing the Pet," 1660 , oil on panel, $27.5 \times 20 \mathrm{~cm}$. The Hague, Royal Picture Gallery Mauritshuis, inv. 108 (artwork in the public domain)

Van Mieris's work became of greater significance to Vermeer around 1660, when the latter began adopting subjects, objects, figure poses, and compositions from the former's paintings. The Delft artist was particularly fascinated by Man and a Woman with Two Dogs, known as "Teasing the Pet" (fig. 2) and The Oyster Meal, dated 1660 and 1661 respectively. These companion pieces first helped Vermeer shape The Glass of Wine (Berlin, Staatliche Museen, Gemäldegalerie). While the 
subject and figure group of this painting derives from ter Borch's Wine Drinking Couple Served by a Page, close observation reveals that the way in which the Delft artist modeled the suitor's cape is based on the male protagonist's garb in van Mieris's "Teasing the Pet." Likewise, the prominent placement of the white faience jug on the corner of the carpeted table is a borrowing from The Oyster Meal. ${ }^{6}$ As van Mieris's pendants serve as a terminus post quem to TheGlass of Wine, Vermeer's painting should be dated to 1661-62, or to 1660 at the earliest, if we assume that the Delft artist had access to The Oyster Meal before it was completed and inscribed with a date. ${ }^{7}$ This possibility should by no means be excluded. In the mid-1660s, Eglon van der Neer (1635/36-1703) and Jacob Ochtervelt (1634-1682) also made variations of van Mieris's Doctor's Visit before it was finished. They presumably studied the painting in the artist's studio in Leiden.

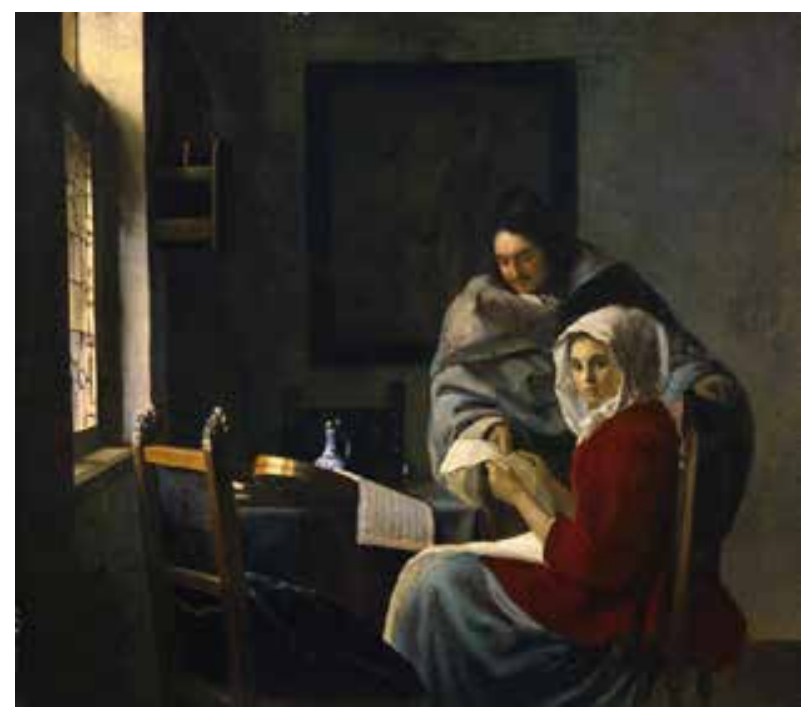

Fig. 3 Johannes Vermeer, Young Woman Interrupted at Her Music, 1660-62, oil on canvas, $39.3 \times 44.4 \mathrm{~cm}$. New York, The Frick Collection, inv. 11.1.125 (artwork in the public domain)

Van Mieris's pendants also served as the principal point of departure for Vermeer's subsequent paintings of amorous encounters. The way in which van Mieris's suitor leans toward his lover (his right shoulder lower than his left) while grabbing the ear of a small spaniel in "Teasing the Pet" inspired Vermeer to paint a gentleman standing beside a lady clutching her music score between his fingers in Young Woman Interrupted at Her Music (fig. 3). The lute lying on the table seen from the rear in van Mieris's picture prompted the Delft artist to paint (what looks like) a guitar in a similar position. ${ }^{9}$ The Oyster Meal, furthermore, was Vermeer's chief source of inspiration when painting Young Woman with a Wine Glass (Braunschweig, Herzog-Anton-Ulrich-Museum). The way in which the grinning gentleman approaches a lady extending his right hand toward her is remarkably close to how van Mieris painted a male suitor offering an aphrodisiac to his young mistress in The Oyster Meal. Vermeer retained the position of the woman's right hand in the center of the composition but substituted the oyster with a glass of wine, which van Mieris's woman holds in her left hand. The fact that white faience jugs appear on the corner of the table in both paintings is, again, not coincidental. ${ }^{10}$ Van Mieris's pendants help us date Young Woman with a Wine Glass to 1660 at the very earliest, but more plausibly to 1661-62. ${ }^{1}$ Mieris's Duet in terms of the orange-red brocade-trimmed dress and the position of the suitor's head in front of the bottom right corner of the black ebony frame. ${ }^{12}$ The Duet, one of the most 
influential genre scenes of the third quarter of the seventeenth-century, remained an important source of inspiration for Vermeer throughout his career. ${ }^{13}$ In the first half of the 1660 s, for instance, it prompted him to paint his own romantic tête-à-tête at a keyboard instrument in Lady at the Virginals with a Gentleman, "The Music Lesson" (Royal Collection, Her Majesty Elizabeth II). ${ }^{14}$ The Delft artist dramatically changed the format of the music scene but could not resist basing the spatial conception of his painting on van Mieris's Cloth Shop and positioning a carpeted table in the right foreground. ${ }^{15}$

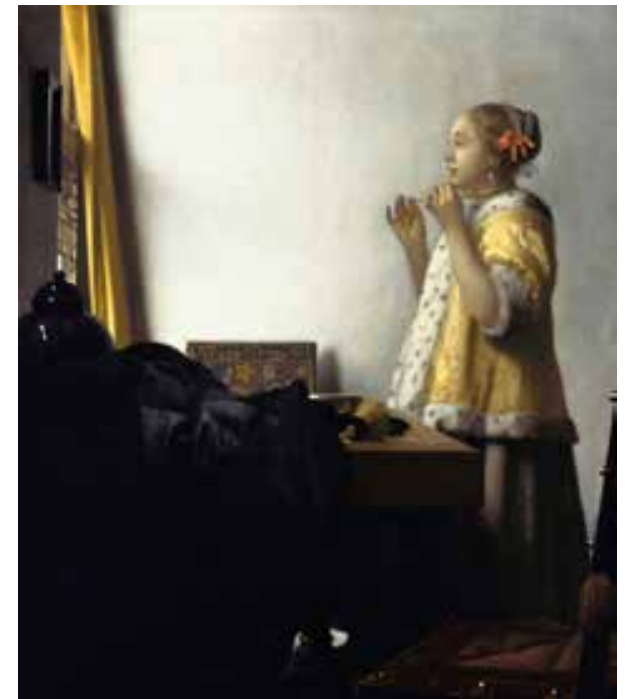

Fig. 4 Johannes Vermeer, Woman with a Pearl Necklace, 1661-63, oil on canvas, $51.2 \times 45.1 \mathrm{~cm}$. Berlin, Staatliche Museen, Gemäldegalerie, inv. 912B (artwork in the public domain)

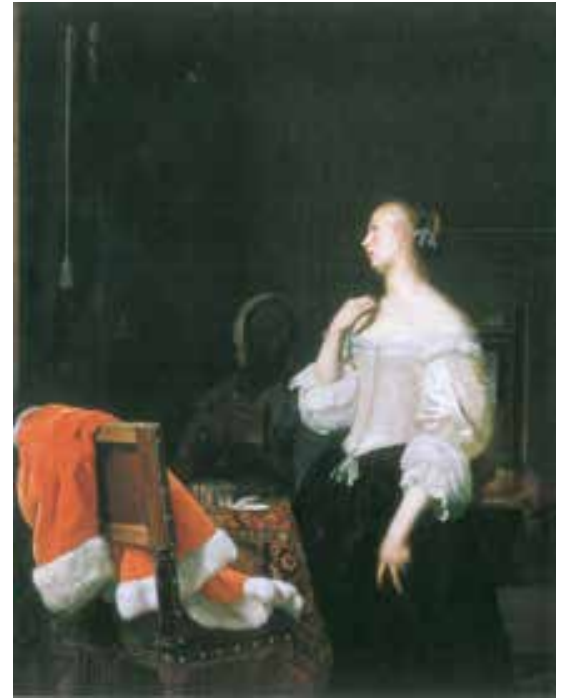

Fig. 5 Frans van Mieris, Woman before a Mirror, ca. 1662, oil on panel, 30 x $23 \mathrm{~cm}$. Berlin, Staatliche Museen, Gemäldegalerie, inv. 838 (artwork in the public domain)

In the mid-1660s Vermeer painted several representations of single women engaged in different domestic activities and pastimes. In preparation for one of them, Woman with a Pearl Necklace (fig. 4), the Delft artist studied Van Mieris's Woman before a Mirror (fig. 5), which represents an elegant young lady in a seductive low-cut satin bodice at her toilet in an opulent interior. The painting inspired Vermeer to repeat the image of a female figure in profile fiddling with a piece of jewelry while observing herself in a looking-glass. He followed his Leiden contemporary in placing the woman in front of a table, positioning a chair in the foreground serving as a repoussoir, and contrasting vertical and horizontal lines. ${ }^{16}$ However, Vermeer abandoned van Mieris's artificial lighting and toned down the aristocratic and seductive character of the scene, instead depicting a toilet scene in a mundane domestic interior basked in natural daylight. ${ }^{1}$

Vermeer continued to appropriate ideas from van Mieris's work in the second half of the 1660s, but to a lesser degree than in the preceding years. ${ }^{18}$ While his Lady Writing (Washington, D.C., National Gallery of Art) is foremost a thematic and compositional variation of ter Borch's Woman Writing a Letter, it shares a number of features with van Mieris's Woman Stringing Pearls, including the figure's posture, the positioning of her body in relation to the table and the chair, and the emphasis on the bows in her hair. ${ }^{19}$ Likewise, the subject of an artist painting a woman dressed up as a Muse in his studio, as represented in Vermeer's Art of Painting (Vienna, Kunsthistorisches Museum,), probably derived from a lost painting by Gabriel Metsu (1629-1667). But two early 
depictions of artist's studios by van Mieris may have served as inspiration to the Delft artist as well. ${ }^{20}$ A stronger connection exists between Young Woman Standing at a Virginal (London, National Gallery) and van Mieris's Duet. Vermeer's music scene owes its subjects, composition, and the relationship between the woman's head and the frame behind on the back wall to van Mieris's painting. ${ }^{21}$ Finally, scholars have compared Vermeer's use of a more schematic, polished technique during the end of his career to van Mieris's shift to a more decorative, stylized manner of painting. Whether the paintings of the Leiden artist served as a direct example for his Delft colleague remains undetermined, however. ${ }^{22}$

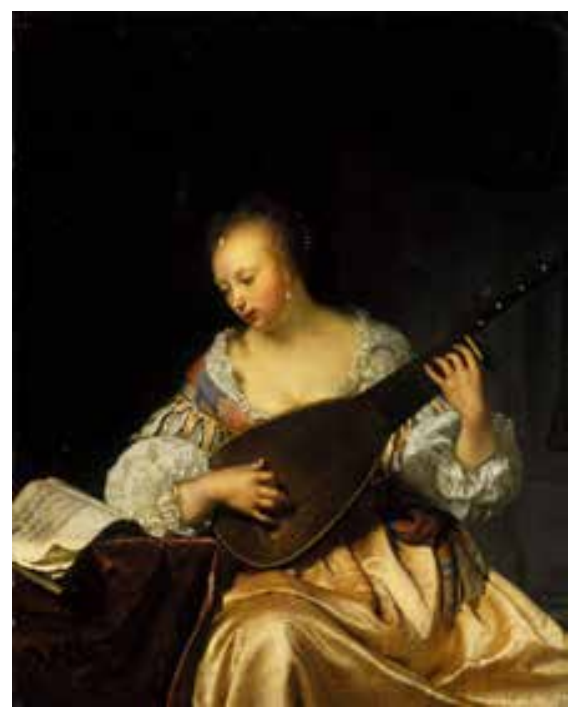

Fig. 6 Frans van Mieris, Woman Playing a Theorbo-Lute, 1663, oil on panel, $22 \times 17 \mathrm{~cm}$. Edinburgh, National Gallery of Scotland, inv. NG 2795 (artwork in the public domain)

Let us now turn our attention to Woman with a Lute (fig. 1) at the Metropolitan Museum of Art. This compelling picture represents a young female tuning her musical instrument while looking to the left through a window next to her as if responding to an outdoor noise or movement. The literature on Vermeer generally discusses the work in the context of contemporary images of single women by the artist's own hand (the "pearl pictures") or other painters' representations of women with plucked string instruments. ${ }^{23}$ However, Vermeer scholars seem to have overlooked the painting's relationship to van Mieris's Woman Playing a Theorbo-Lute (fig. 6). ${ }^{24}$ Dated 1663, this remarkable picture was for a long time known only through a black-and-a-white photograph. It resurfaced in 1998 before being passed on to the National Gallery of Scotland, Edinburgh, in 2005. ${ }^{25}$ The Leiden artist represented a three-quarter-length figure playing a theorbo-lute and dressed in a flamboyant outfit. He placed her in an interior with a green curtain, a marble floor, and a classical pilaster. She looks sideways to read the score on the table, which creates a remarkable balance between the woman's gaze directed to the left and the neck of the lute extending to the right. Although van Mieris's woman tunes rather than plays the lute, her pose bears a striking resemblance to that of Vermeer's musician. In fact, it cannot be a coincidence that the Delft artist, who appropriated a number of figure poses from van Mieris's work in the first half of the 1660 s, painted a woman playing a lute in a remarkably similar position.

9 A comparison between van Mieris's and Vermeer's paintings, however, indicates that, with the exception of the woman's pose, the two works strongly differ. The Leiden painter created a contrived image of a seductive courtesan dressed in clothes uncharacteristic of Dutch fashion of the 
early 1660s and seated in an opulent interior. Vermeer painted a middle-class woman in a Dutch interior surrounded by mundane objects (with the exception of the lute itself and the map behind her, which were costly items). Whereas van Mieris placed his musician close to the picture plane against a dark background, his Delft contemporary positioned his figure at some distance from the viewer in a clearly defined room, based on linear perspective and filled with natural daylight. The former used his typically minute painting technique with defined contours and sharp highlights to create recognizable materials. Vermeer went in the opposite direction, painting fuzzy transitions and slightly schematic surfaces that fail to describe textures in detail.

10 Given the fact that Vermeer painted Woman with a Lute around the same time or shortly after his Leiden contemporary completed his picture, it seems the two works were part of a direct artistic rivalry. ${ }^{26}$ We may presume the Delft artist set out to surpass his contemporary by creating a work of art with the same thematic and formal starting point but that was less aristocratic and lascivious in character and more virtuoso in terms of light and space. These changes echo the way in which Vermeer altered van Mieris's Woman before a Mirror (fig. 5) to arrive at Young Woman with a Pearl Necklace (fig. 4).

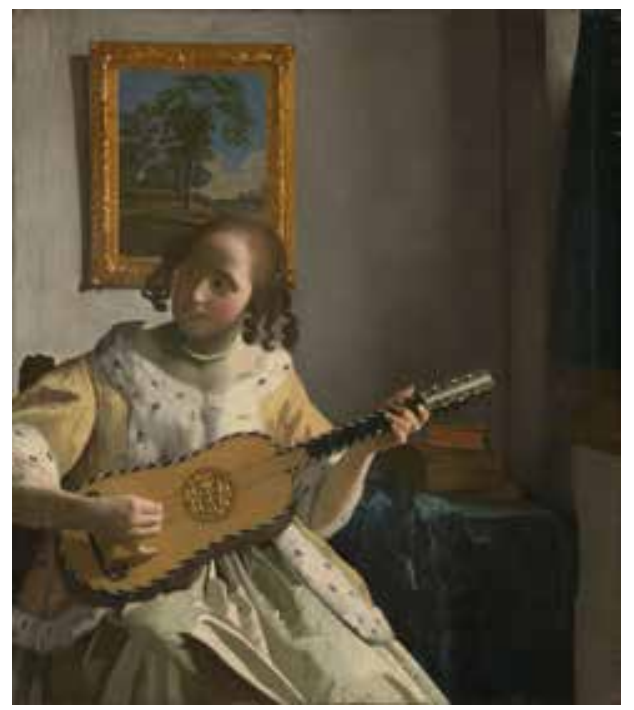

Fig. 7 Johannes Vermeer, The Guitar Player, 1670-72, oil on canvas, 51.4 x $45 \mathrm{~cm}$. London, Kenwood House, The Iveagh Bequest, inv. 88028841 (artwork in the public domain)

11 Vermeer's admiration for van Mieris's Woman Playing a Theorbo-Lute was not a whim. He employed the figure pose again in The Guitar Player (fig. 7) in the early 1670s. The Delft artist deviated again from the work of his Leiden contemporary by depicting a middle-class woman in contemporary clothes in a typically Dutch interior. Like the protagonist in Woman with a Lute, she turns her head sideways in response to a distraction outside the pictorial space. A few similarities between Vermeer's Guitar Player and van Mieris's Woman Playing a Theorbo-Lute are worth noting, however. The Delft artist positioned her close to the picture plane, as van Mieris had done. While substituting the lute with a guitar, Vermeer also represented her playing rather than tuning the instrument. The position of her right knee and the way in which the folds of the satin dress are draped around it, furthermore, are remarkably similar to what can be seen in van Mieris's painting. Finally, the increasingly polished surfaces and textures found in Vermeer's painting echo those in the work of his Leiden contemporary. ${ }^{27}$ 
12 If Vermeer's aim was to surpass van Mieris's picture, he did not convince contemporary genre painters. Neither Vermeer's Woman with a Lute, nor The Guitar Player served as inspiration to other seventeenth-century artists. ${ }^{28}$ Van Mieris's Woman Playing a Theorbo-Lute, by contrast, made a strong impact on several Dutch artists. Caspar Netscher (1639-1684) from The Hague painted two variations in the late 1660s to early 1670 s..$^{29}$ Eglon van der Neer (1634-1703), while living in Rotterdam, painted no fewer than six variations of van Mieris's composition, all deviating in different aspects from their example. ${ }^{30}$ Woman Playing a Theorbo-Lute remained popular during the late seventeenth and early eighteenth centuries, serving as inspiration to, among others, Michiel van Musscher (1645-1705), WillemVerschuring (1665/67-1715/27), Pieter van der Werff (1665-1722), and Phillip van Dijk (1683-1753).

13 Despite its initial popularity, van Mieris's painting today lacks the fame of Vermeer's two canvases. The exhibition Vermeer and the Masters of Genre Painting: Inspiration and Rivalry, to be held in 2017-18, will bring van Mieris's paintingand Vermeer's Woman with a Lute together for the first time. ${ }^{32}$ This juxtaposition will give visitors a chance to compare the two works and decide for themselves whether the Delft artist succeeded in surpassing his Leiden contemporary.

Adriaan Waiboer received an MA and a PhD at the Institute of Fine Arts, New York University in, respectively, 1998 and 2007. He has been Curator of Northern European Art at the National Gallery of Ireland, Dublin, since 2004. Waiboer's monograph with catalogue raisonné on Gabriel Metsu appeared in 2012. He is currently preparing the exhibition Vermeer and the Masters of Genre Painting: Inspiration and Rivalry, which will be on view in Paris, Dublin, and Washington, D.C., in 2017-18).

AWaiboer@ngi.ie

\section{List of Illustrations}

Fig. 1 Johannes Vermeer, Woman with a Lute, ca. 1662-64, oil on canvas, 51.4 x $45.7 \mathrm{~cm}$. New York, The Metropolitan Museum of Art, Bequest of Collis P. Huntington, 1900, inv. 25.110.24 (artwork in the public domain)

Fig. 2 Frans van Mieris, Man and a Woman with Two Dogs, known as "Teasing the Pet," 1660, oil on panel, 27.5 x $20 \mathrm{~cm}$. The Hague, Royal Picture Gallery Mauritshuis, inv. 108 (artwork in the public domain)

Fig. 3 Johannes Vermeer, Young Woman Interrupted at Her Music, 1660-62, oil on canvas, $39.3 \mathrm{x}$ $44.4 \mathrm{~cm}$. New York, The Frick Collection, inv. 11.1.125 (artwork in the public domain)

Fig. 4 Johannes Vermeer, Woman with a Pearl Necklace, 1661-63, oil on canvas, $51.2 \times 45.1 \mathrm{~cm}$. Berlin, Staatliche Museen, Gemäldegalerie, inv. 912B (artwork in the public domain)

Fig. 5 Frans van Mieris, Woman before a Mirror, ca. 1662, oil on panel, 30 x $23 \mathrm{~cm}$. Berlin, Staatliche Museen, Gemäldegalerie, inv. 838 (artwork in the public domain)

Fig. 6 Frans van Mieris, Woman Playing a Theorbo-Lute, 1663, oil on panel, 22 x $17 \mathrm{~cm}$. Edinburgh, National Gallery of Scotland, inv. NG 2795 (artwork in the public domain)

Fig. 7 Johannes Vermeer, The Guitar Player, 1670-72, oil on canvas, 51.4 x $45 \mathrm{~cm}$. London, Kenwood House, The Iveagh Bequest, inv. 88028841 (artwork in the public domain) 
${ }^{1}$ Wayne Franits, Vermeer (London and New York: Phaidon, 2015), 131-32.

${ }^{2}$ Edouard Plietzsch, Vermeer van Delft (Munich: Bruckmann, 1939), 41.

${ }^{3}$ Otto Naumann, Frans van Mieris (1635-1681) The Elder (Doornspijk: Davaco, 1981), 1:48-62.

${ }^{4}$ Walter Liedtke, Vermeer: The Complete Paintings (Antwerp: Ludion, 2008), 32, 75, 81. John Michael Montias in Vermeer, Albert Blankert, John Michael Montias, and Gilles Aillaud (New York: Rizzoli, 1988), 40, suggested (referencing Otto Naumann) that Vermeer's response to the Leiden artist can already be found in The Procuress (Dresden, Staatliche Kunstsammlungen, Gemäldegalerie Alte Meister) of 1656. This painting includes a self-portrait as a musician with a beret smiling at a viewer, which is supposedly a variation of a similar figure in van Mieris's Charlatan (Florence, Galleria degli Uffizi). However, Vermeer's figure is more closely related to musicians appearing in brothel scenes by Dutch caravaggist painters such as Dirck van Baburen, to which Vermeer's Procuress also relates in style and subject matter (see, for instance, Liedtke, Vermeer, 63, figs. 3a, b). See also Naumann, Frans van Mieris, 1:99). Liedtke, Vermeer, 45-46, argued that the pointilé highlights in van Mieris's Woman Stringing Pearls (Montpellier, Musée Fabre) resemble those in works such as The Milkmaid (Amsterdam, Rijksmuseum). The direction of influence is unclear, however. ${ }^{5}$ On the relationship between The Glass of Wine and ter Borch's painting, see, for instance, Liedtke, Vermeer, 81

${ }^{6}$ Naumann, Frans van Mieris, 1:61.

${ }^{7}$ Vermeer's painting is generally dated earlier, to 1660-61 (Albert Blankert, with contributions by Rob Ruurs and Willem L. van de Watering, Johannes Vermeer van Delft 1632-1675 [Utrecht and Antwerp: Het Spectrum, 1975] 143); to 1658-60 (Arthur K. Wheelock Jr, Jan Vermeer [New York: Harry N. Abrams, 1981], 90); to 1658-59 (Liedtke, Vermeer, 80); and to ca. 1659-60 (Franits, Vermeer, 92).

${ }^{8}$ Eddy Schavemaker, Eglon van der Neer (1635/36-1703): His Life and His Work (Doornspijk: Davaco, 2010), 53, 55.

${ }^{9}$ Naumann, Frans van Mieris, 1:61, 64.

${ }^{10}$ Rüdiger Klessmann, Die Sprache der Bilder: Realität und Bedeutung in der niederländisches Malerei des 17. Jahrhunderts, exh. cat. (Braunschweig: Herzog-Anton Ulrich-Museum, 1978), 165, was the first to notice the relationship between van Mieris's and Vermeer's paintings. See also previous note.

${ }^{11}$ Franits, Vermeer, 126, made the point that a date of 1659-60 for Vermeer's Young Woman with a Wine Glass, as had been previously suggested (for instance, Liedtke, Vermeer, 86), is too early. A date of 1661-62, as Franits suggested, is more likely.

${ }^{12}$ Blankert, Johannes Vermeer, 60.

${ }^{13}$ Van Mieris's Duet served as inspiration to at least thirteen works by Gabriel Metsu, Jan Steen, Quiringh van Brekelenkam, Caspar Netscher, and Jacob Ochtervelt (see https://rkd.nl/ explore/images/239211).

${ }^{14}$ Blankert, Johannes Vermeer, 66.

${ }^{15}$ Plietzsch, Vermeer, 41. Blankert, Johannes Vermeer, 60, also suggested that van

Mieris's Duet served as an important example to Vermeer as an image of a monumental figure placed against a bright back wall.

${ }^{16}$ See, for instance, Arthur K. Wheelock Jr. in Johannes Vermeer, exh. cat., ed. Arthur K. Wheelock Jr. and Ben P. J. Broos (Washington, D.C.: National Gallery of Art, and The Hague: Royal Picture Gallery Mauritshuis, 1995-96), 152, and Liedtke, Vermeer, 116. Earlier, Naumann, Frans van Mieris, 1:68, argued that the direction of influence between the paintings was unclear due to 
the lack of dates on both works. While van Mieris's painting has been dated to ca. 1662 (Naumann, Frans van Mieris, 2:56-59, pl. 46), scholars have proposed the following dates for Vermeer's picture: 1662-65 (Blankert, Montias, and Aillaud, Vermeer, 179-80), 1664 (Wheelock, Jan Vermeer, 110), 1663-64 (Liedtke, Vermeer, 115-17), and 1662-65 (Franits, Vermeer, 140).

${ }^{17}$ Liedtke, Vermeer, 45, put forward that van Mieris's Young Woman Stringing Pearls of 1658 (Montpellier, Musée du Fabre) "anticipates two [paintings] by Vermeer," hinting at A Lady Writing (Washington, D.C., National Gallery of Art) and Mistress and Maid (New York, Frick Collection).

${ }^{18}$ Blankert, Johannes Vermeer, 68, suggested that van Mieris's Portrait of the Artist's Wife, Cunera de Cock may have been Vermeer's source of inspiration when painting his Girl with the Pearl Earring (The Hague, Royal Picture Gallery Mauritshuis). While it is possible that van Mieris's work played a role in the conception of Vermeer's tronie, some of Michiel Sweerts's paintings, including A Young Maidservant (The Kremer Collection, Fondation Aetas Aurea), were of much greater significance for the Delft artist (see, for instance, Liedtke, Vermeer, 132). See also Naumann, Frans van Mieris, 1:64n4, who saw a relationship between van Mieris's portrait and the three female figures in Vermeer's Cavalier and Young Woman, Young Woman with a Water Pitcher (New York, Metropolitan Museum of Art), and Woman with a Balance (Washington, D.C., National Gallery of Art).

${ }^{19}$ On the relationship between Vermeer's Lady Writing and ter Borch's Woman Writing a Letter (The Hague, Royal Picture Gallery Mauritshuis,), see, for instance, Wheelock, Jan Vermeer, 124.

${ }^{20}$ Lawrence Gowing, Vermeer (London: Giles de la Mare, 1952), 142n107; Adriaan E. Waiboer, "Why buy a Vermeer when a Metsu is available?': The Relationship between Two Dutch Genre Painters", in Gabriel Metsu, exh. cat., ed. Adriaan E. Waiboer (Dublin: National Gallery of Ireland; Amsterdam: Rijksmuseum; Washington, D.C.: National Gallery of Art, Washington, 2010-11), 33-34; Blankert, Johannes Vermeer, 71; Liedtke, Vermeer, 144-46.

${ }^{21}$ Plietzsch, Vermeer, 41.

${ }^{22}$ Blankert, Johannes Vermeer, 78; Naumann, Frans van Mieris, 2:119. Naumann (2:28) also suggested that van Mieris's Portrait of a Woman, a striking image of a woman wearing an ostentatious green beret, may have stimulated Vermeer to paint Girl with a Red Hat (Washington, D.C., National Gallery of Art), but this is hard to establish with certainty.

${ }^{23}$ See, for instance Wheelock, Jan Vermeer, 112; Liedtke, Vermeer, 101; Franits, Vermeer, 132, 139. Gowing, Vermeer, 40, coined the term "pearl pictures."

${ }^{24}$ The only scholar who seems to have noticed the connection between the two paintings is Naumann, Frans van Mieris, 1:64, who mentioned in passing that Van Mieris's Woman with a Theorbo-Lute "probably served as the basis for Steen's and Vermeer's excursions into the subject" without further elaborating this point. E. Korthals Altes in Senses and Sins: Dutch Painters of Daily Life in the Seventeenth Century, exh. cat., ed. Jeroen Giltaij et al. (Rotterdam: Museum Boijmans Van Beuningen, Rotterdam, and Frankfurt am Main: Städelsches Kunstinstitut, 2004-5), referenced van Mieris's painting in an entry on Vermeer's but did not identify it as the Delft artist's source of inspiration.

${ }^{25}$ I am grateful to Christian Tico Seifert for clarifying the recent provenance of van Mieris's painting to me (personal communication).

${ }^{26}$ Although the direction of influence is not documented, it is highly unlikely Vermeer's painting preceded van Mieris's work, considering his strong reliance on the work of the Leiden painter 
in the first half of the 1660s. While van Mieris's painting is inscribed 1663, Vermeer's is variably dated to ca. 1664 (Wheelock, Jan Vermeer, 112), 1662-63 (Liedtke, Vermeer, 101), ca. 1662-65 (Franits, Vermeer, 141). Note that Liedtke dated this as well as a number of other paintings by Vermeer earlier than other scholars have done (see http://www.essentialvermeer.com/references/ dates.html\#.Vm6v49KyOko ) and in the opinion of the present author too early (see also note 11 above). A date of 1662-64 for A Woman with a Lute is more appropriate. This date takes into account that Vermeer may have seen van Mieris's painting before it was completed.

${ }^{27}$ Naumann, Frans van Mieris, 1:67, previously argued: “Also close to Van Mieris's Woman Playing the Lute is Vermeer's late guitar player in Kenwood House, which exhibits similar concerns for smooth surface and polish finish."

${ }^{28}$ The only exception is an anonymous copy after a The Guitar Player from ca. 1700 (see Blankert, Montias, and Aillaud, Vermeer, 192).

${ }^{29}$ Majorie E. Wieseman, Caspar Netscher and Late Seventeenth-Century Dutch Painting (Doornspijk: Davaco, 2002), 227, no. 84; 252, no. 119 (both illustrated).

${ }^{30}$ Schavemaker, Eglon van der Neer, 466, no. 39 (ill.); 468-69, no. 46 (ill.); 470, no. 52 (ill.); 477, no. 63, color pl. XXI; 481, no. 73 (ill.); 485-86, no. 83, color pl. XXVII.

${ }^{31}$ Naumann, Frans van Mieris, 1: 67; for van Musscher's, see https://www.mbam.qc.ca/en/collections/early-to-modern-international-art/ - detail-8700; Junko Aono, Confronting the Golden Age:

Imitation and Innovation in Dutch Genre Painting 1680-1750 (Amsterdam: Amsterdam University Press, 2015), 28-30, with illustrations of Verschuring's, van der Werff's, and van Dijk's paintings. http://dx.doi.org/10.5117/9789089645685

${ }^{32}$ Held at the Musée du Louvre, Paris, the National Gallery of Ireland, Dublin, and the National Gallery of Art, Washington, D.C.

\section{Bibliography}

Aono, Junko. Confronting the Golden Age: Imitation and Innovation in Dutch Genre Painting 16801750. Amsterdam: Amsterdam University Press, 2015. http://dx.doi.org/10.5117/9789089645685

Blankert, Albert, with contributions by Rob Ruurs and Willem L. van de Watering. Johannes Vermeer van Delft 1632-1675. Utrecht and Antwerp: Het Spectrum, 1975.

Blankert, Albert, John Michael Montias, and Gilles Aillaud. Vermeer. New York: Rizzoli, 1988.

Franits, Wayne. Vermeer. London and New York: Phaidon, 2015.

Giltaij, Jeroen, et al. Senses and Sins: Dutch Painters of Daily Life in the Seventeenth Century. Exh. cat. Rotterdam: Museum Boijmans Van Beuningen, and Frankfurt am Main, Städelsches Kunstinstitut, 2004-5.

Gowing, Lawrence. Vermeer. London: Giles de la Mare, 1952.

Klessmann, Rüdiger. Die Sprache der Bilder: Realität und Bedeutung in der niederländisches Malerei des 17. Jahrhunderts. Exh. cat. Braunschweig: Herzog-Anton Ulrich-Museum, 1978. 
Liedtke, Walter. Vermeer: The Complete Paintings. Antwerp: Ludion, 2008.

Naumann, Otto. Frans van Mieris (1635-1681) The Elder. 2 vols. Doornspijk: Davaco, 1981.

Plietzsch, Edouard. Vermeer van Delft. Munich: Bruckmann, 1939.

Schavemaker, Eddy. Eglon van der Neer (1635/36-1703): His Life and His Work. Doornspijk: Davaco, 2010.

Waiboer, Adriaan E. “Why buy a Vermeer when a Metsu is available?': The Relationship between Two Dutch Genre Painters. ” In Gabriel Metsu, edited by Adriaan E. Waiboer, 29-51. Exh. cat. Dublin: National Gallery of Ireland; Amsterdam: Rijksmuseum; Washington, D.C.: National Gallery of Art, 2010-11.

Wheelock, Arthur K., Jr. Jan Vermeer. New York: Harry N. Abrams, 1981.

Wheelock, Arthur K., and Broos, Ben P. J. Johannes Vermeer. Exh. cat. Washington, D.C.: National Gallery of Art, and The Hague: Royal Picture Gallery Mauritshuis, 1995-96.

Wieseman, Majorie E. Caspar Netscher and Late Seventeenth-Century Dutch Painting. Doornspijk: Davaco, 2002.

\section{Recommended Citation:}

Adriaan E. Waiboer, "A View beyond Delft: Johannes Vermeer's Woman with a Lute and Its Relationship to Frans van Mieris," JHNA 9:1 (Winter 2017), D0l: 10.5092/jhna.2017.9.1.16 